\title{
Investigating The Challenges Of E-Learning In A Developing Institution Of Higher Learning: A Hypothetical Approach
}

Albert Tchey Agbenyegah, Durban University of Technology, South Africa Bongani Innocent Dlamini, Durban University of Technology, South Africa

\begin{abstract}
The popularity of e-learning (EL) largely infiltrated into every sector of South African institutions of higher learning. This growing interest in EL is due to the advent of rapid internet technologies. For decades, South African institutions of higher learning have accepted EL as a vital learning tool for the enhancement of learning and teaching within the higher education sector. However, there are countless challenges that continue to hinder learning and teaching activities. This study seeks to determine the relationships between various challenges and EL capabilities through stated hypotheses. The study is a descriptive, qualitative design aided by a quantitative approach that were applied to collect data. In total 150 full and part-time ICT students including four permanent ICT lecturers participated in the study. By means of statistical methods of descriptive, inferential statistics aided by independent t-tests, three stated hypotheses were formulated and tested. The study therefore, recommends that higher institutions of learning should increase investments in various EL programs including relevant ICT infrastructure development and also in levels of connectivity. The study further recommends that EL contents should be designed taking into account the cultural characteristics of students.
\end{abstract}

Keywords: E-Learning; Developing University; Challenges; ICT Infrastructure

\section{INTRODUCTION}

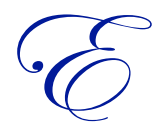

-learning is largely known within the higher education sector for two reasons; its dramatic changes to the existing educational climate and its ability to enhance learning and teaching. Further to these achievements, scientific literature supports the notion that EL has evolved over the years in addition to supporting distance learning programs (Sangra, Vlachopoulos \& Cabrera, 2012). E-learning is described as different fields of online learning namely, the web-based training and instruction through technological appliances (Oye, Salleh \& Iahad, 2010). Recent study by the OECD (2005) shows that EL is alternative to the traditional online learning. While EL has the potential to allow South African students to attain set objectives, EL across the higher education sector of South Africa is faced with challenges of skilled employees. Thus, the students at the institution are increasingly faced with multitudes of challenges including personal, institutional, lack of technical support and demographic challenges and this continues to be of utmost concern. It is therefore, critical that these challenges are carefully managed to sustain EL at higher institutions of learning. This study seeks to determine among others, the relationships between E-learning personal challenges (ELPCs) as well as in higher institutions of learning. The study was conducted in the organization; it involved the full and part-time ICT students and permanent lecturers in ICT courses. In this study, EL includes information and Communication Technology (ICT) equipment such as computers, the internet, mobile phones, televisions and radio appliances. This study is in three main sections. Initially the study provided an in-depth literature review, the theoretical and conceptual framework that leads to the formulation of the hypotheses to be tested. The second section of this study entails the chapter on methodology, data analysis as well as the discussion of results. Finally, the study ended with section on the conclusion and recommendations. 


\section{LITERATURE REVIEW}

\section{Contextualizing the Present Study}

Two employees within the institution in South Africa initiated the study. These employees were employed and tasked with the traditionally teaching and learning to full and part-time students of the institution. Based on their personal convictions, the employees decided to find out what were the stumbling blocks to EL activities. In general, EL strategies form part of the teaching and learning portfolio designed to enhance academic performances of the students. Its main focus was the applications of ICT tools such as computers, internet as well as to utilise the broad-band connectivity. For smooth running of EL in higher education institutions including the institution, the authors of this study believe that proper skills training of lecturers, upgrades of existing infrastructure and constant updates of equipment are required. According to Hardgrave and Johnson (2003), issues relating to technology are some of the vital reasons for growing resistance based on end-users' perceptions. From scientific perspectives, technology is known to impact on information dissemination, quality teaching, and creation of valued-based knowledge assessment (Rienties, Brouwer \& Lygo-Barker, 2013). As a result, identifying EL challenges are considered by the authors of this study as an outstanding focal issue (Hsiao \& Yang, 2011). Drawing from these understandings, the authors were keen to determine some of the EL challenges with which the ICT students are faced.

Conducting this study is useful for two reasons. Initially, the feedback could assist in providing the necessary improvement to the various underlining components of the existing teaching and learning portfolio. Knowing and understanding the various EL challenges would enable the management of the institution to increase the present human capital base. This study offers the best opportunity for potential delivery of teaching and ICT learning among the students. According to the authors, studies such as this provides practical solutions to the roles of science and technology in an educational environment (Reddy, Gastrow, Juan \& Roberts, 2013; Flipsen \& Van der Weide, 2009).

\section{THEORETICAL FRAMEWORK - EL CHALLENGES}

The concept of challenge is likely to be parallel to barriers. As Stevenson (2010) put it, a challenge is a situation that tests one's aptitudes, one's action that generates the least form of obstruction; thus, its central focus is either to block or retard specific progress. Drawing from this definition, researchers Horn, Huygen, Woodward and Smith (2009) add that barriers on the other hand, are similar concepts that hamper easy activities or movements. Others argued that a challenge represents a strong physical object that requires enormous human effort for successful implementation (Nani, 2011). Several studies defined the concept of EL as learning and communication activities that entails the application of computers, networks and other electronic devices (Wong, 2007; Sambrook, 2003). Throughout this study EL challenges are defined as the barriers within the context of EL within higher education system that constraints the learning and teaching processes (LTP). Besides, ELPCs within the educational context is seen as core barriers in achieving the benefits of learning and teaching objectives by ICT students.

\section{ELPCs in educational context}

In broad terms, EL education entails infusing the present-day telecom unication and ICT resources to stimulate interactions for better education experiences ( Du, Fu, Zhao, Liu \& Liu, 2013). According to Lee, Hsieh, and Hsu (2011), infusing EL as part of technology impacts positively on the general attitudes and behaviours of students. Lately, EL has been viewed as synonymous with the latest tools to access high quality education. EL represents flexible learning through networks that focus on tools and applications of information among learners (Moll, Adam, Backhouse \& Mhlang, 2007). Whilst there have been swift changes in education since the advent of EL, the higher education sector in particular impacts on society since it has enormous duties towards the general education system (Sanyal, 2001.

As a result, the roles of educators and students have seen similar changes as EL offers substantial business opportunities for disadvantaged individuals (Dumbrajs, Jagerb \& De. Bergström-Nybergc, 2013). For example, ICT students are easily employable in various economic climates. Also, ICT educators are able to offer additional services across different economic sectors. Globally, ICT equipment such as high speed computers make the learning climate readily available to students for hours (Rubens, Kaplan \& Okamoto, 2011). 
In spite of its recognition within the higher education sector, EL is without challenges. Several studies were done on EL challenges in developed and developing countries (Andersson \& Gronlund, 2009; Omidinia, Masrom \& Selamat, 2011; Sife, Lwoga, \& Sanga, 2007). These challenges stem from personal, technical and institutional climates. Given these challenges, students from poorer communities and disadvantaged backgrounds are most likely to perform below expected standards. These occurrences require mixed and not complex approaches. Jaffer, N'gambi and Czerniewicz, (2007) posit that prior learning as well as changing learning habits contribute to improvement in performances and ELPCs. Yet within the education sector, personal challenges include inadequate use of time and scarce resources as well as individual demographic issues that continue to influence EL (OERAfrica, 2014; Isabirye \& Dlodlo, 2014). Aside from the primary objectives, this study seeks to find the relationship between selected challenges and ELPCs as hypothesized.

\section{CONCEPTUAL FRAMEWORK}

Several scientific evidences exist for decades on EL challenges in developing countries such as Egypt, Tanzania, Nigeria and Uganda (Abdel-Wahab, 2008; Kituyi \& Kyeyune, 2012; Bhalalusesa, Lukwaro \& Clemence, 2013). Throughout these studies, it emerged that the ICT sector experienced countless impediments as a result of infrastructure, discrepancies in cultural needs as well as lack of knowledge transfer across ICT programs (Kohn, Maier \& Thalmann, 2008). Bhalalusesa et al. (2013) and Omidinia et al. (2011) demonstrated that it is difficult to acquire infrastructure components such as computers and internet access in most developing countries. Another area of concern is the growing lack of qualified employees to perform installation tasks on the limited technology equipment. Jaansen van Vuuren and Coetzee (2004) add that other technological challenges include high costs of resources and the increasing of insufficient telecommunication infrastructure. This implies therefore, that numerous challenges especially inadequate infrastructure components hamper EL in the higher education sector. This is true especially in South Africa where most students cannot afford their own computers and to access the internet (Czernierwicz, Ravjee, \& Mlitwa, 2006).

In developing countries most students within the higher education sector struggle to use EL materials and programs. According to Roffe (2004), the majority of students are either afraid of technology or lack of requisite exposure. These may be true as students are not provided with adequate academic support due to chronic shortages of academic staff and work overload.

At institutional level, studies confirmed that ICT content is very complex. Issues of courses designs, support functions, complex ICT delivery mode and lack of simplified ICT languages continue to dominate ongoing discussions (Omidinia et al. 2011). At the same time, the use of e-learning in the higher education sector raises financial and strategic challenges (Levine \& Sun, 2002). This is because higher institutions are compiled to out-source additional funds and resources for the upkeep not only for equipment, but also for technical support as well as for students and to plough back funds into training and educational initiatives. The notion that the higher education authorities are forced to sell the idea of technology to staff members is another worrying factor (Mackeog \& Fox, 2009).

Given the outcomes of the existing literature review on EL challenges and e-learning personal challenges (ELPCs), the study developed a conceptual framework as shown in figure 1 below to determine the relationships between the EL challenges. 
Figure 1. Conceptual framework of EL challenges

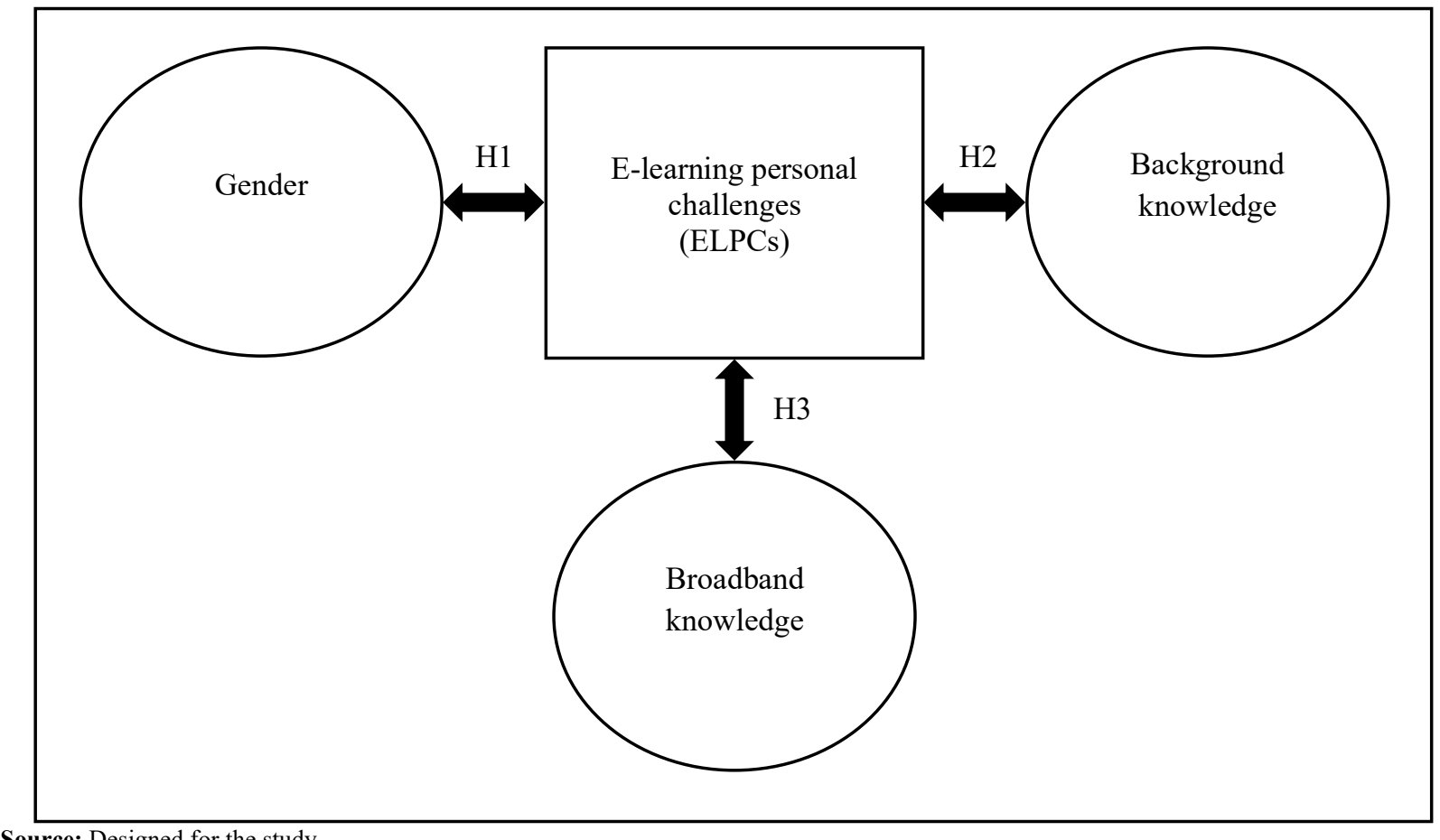

Source: Designed for the study

\section{RESEARCH HYPOTHESES}

Drawing from the conceptual framework above, the following hypotheses were formulated:

H1: There is no significant differences between male and female participants in terms of ELPCs

$\mathbf{H}_{2}$ : There is no significant differences between participants with computer background knowledge and participants without computer background knowledge in terms of ELPCs

H3: There is no significant differences between participants with broadband knowledge and participants without broadband knowledge in terms of ELPCs.

\section{METHODOLOGY}

\section{Research Design}

The study seeks to investigate the relationships between various challenges of e-learning through stated hypotheses at the institution. This study is descriptive as both the quantitative and qualitative methods were applied. Justifications for the descriptive format is that it allows not only for generalisation of the study outcomes, but it also provides enough descriptions of affairs regarding the study problems (Kombo \& Tromp, 2006; Leedy \& Ormrod, 2005). Furthermore, for the authors to develop, clarify, verify as well as to refine specific core issues, a convergent in-depth interview protocol is pursed in addition to questionnaires. Contrast to quantitative study, the authors applied an extensive review of relevant literature for additional data during the course of the study (Bryman, 2012). 


\section{Participants}

The participants in this study were full and part-time ICT students. Further information for the study was provided by four full time ICT lecturers. From the target population of 190 ICT students and permanent employed ICT lecturers, a research sample of $(N=150)$ was sampled by means of purposive and convenience methods (Royse, 2008). Convenience and purposive sampling techniques were used in search of relevant and reliable information form the students (Kent, 2007; Cooper \& Schindler, 2008). For added reliability and credible data set, a determination was made to sample only ICT students and ICT lecturers. Detailed information regarding involuntary participation and ethical consent was provided to participants.

A total of 150 full and part-time students and four ICT lecturers with ages ranging from 18 to 55 years were involved in the study. The full and part-time students' ages ranged from 18 to 25 years with a mean of 34.6 years while the ages of ICT lecturers were between 35 and 55 years with a mean of 7.4 years. Twenty-five per cent of full and part-time students were males while the remaining seventy-five per cent were females. Regarding educational qualifications, twenty per cent of the participating students were in their third year, thirty-five per cent were second year students while the remaining forty-four per cent were first year students. All the students enrolled to pursue their national diploma in different disciplines. However, the authors discovered that ten per cent of the third-year students were repeaters. Out of the four ICT lecturers, none of them acquired the highest qualifications in ICT. However, at least all the ICT lecturers had the minimum ICT qualifications. Most participants were the products of the local high schools. Simply put, the majority of the students were from "disadvantaged feeder schools" from the local communities. Most of these "feeder schools" were built and equipped during the previous regime; thus, each high school lacked the necessary educational resources including basic ICT equipment.

\section{Instrumentation and Data Collection}

Structured questionnaires were used to support the qualitative instrument. The structured questionnaires and interview schedules were designed with similar questions. However, some specific questions were designed for ICT lecturers. Participants in the study were literate; as such, the questionnaires were completed without assistance. The structured questionnaire was in the form of a five-point Likert-scale ranging from (5) strongly disagree to (1) strongly agree. Key contents of the study questionnaire and interview schedule include participants' information such as sex, age, race, field of study and the period of study. Other sections of the questionnaires and the interview schedule was information designed for the ICT lecturers. Information such as the number of years of lecturing experience and their highest academic qualifications also formed part of the structured questionnaires. Section $\mathrm{C}$ of the questionnaire and the interview schedules contained 10 items that were used to measure the degree of EL challenges among the ICT students. These challenges centered on technical support, infrastructure, computer skills and internet connectivity. Sections D and $\mathrm{E}$ were designed to include challenges on technical support, personal, skills and challenges on prior computer knowledge.

Content and face validity were applied through a broader subjective impression of the questionnaire items. The authors used a pilot study through research sample of 40 ICT students and one ICT lecturer. Suggestions and amendments were acknowledged as part of the final questionnaires for more clarity and simplicity of questions. As stated by Merriam (2009), the authors performed a reliability test for internal consistency on items and found (0.74) acceptable; thus, the instrument for the study was reliable (Leontitsis \& Pagge, 2007).

An in-depth interview aided by focus groups was applied to investigate the general views and individual opinions of the ICT students in various ways. In total 150 full and part-time ICT students and their lecturers at the institution participated in the study. The authors ensured that all the ICT students were registered members of the institution at the time of the study. In order to gather credible information regarding EL challenges, a convenience sampling method was employed to identify prospective ICT students and their lecturers. The authors engaged participants during the interview processes at the same time, voice recording instruments supported short and detailed notes as the interview progressed for future coding practices. Equally the authors sought permission from the ICT students and their lecturers during the course of the interview processes. As the processes unfolded, the authors noted that every niche of the entire interview process stimulated participants for further discussions. Thus, the authors were able to prompt more questions for answers. One of the significant benefits of applying an in-depth interview during this study was that the 
process created the possibilities for the authors to clarify, verify and refine the main central issues of the interviews process; thus, in comparison to quantitative study, this qualitative study is an enduring process that represents critical sources of research data (Bryman, 2012).

By all accounts this study adopted a triangulation method in that, besides using in-depth interviews, the authors applied a focus group technique to collect information from the ICT lecturers. Due to lack of time and other resources, all the ICT lecturers were interviewed in one group for a period of 15 minutes in a venue allocated within the premises of the institution. In line with its definition, the authors were able to ask questions relating to participants' opinions, beliefs, individual attitudes and perceptions regarding the research concept (Wilson, 2010). In addition, the authors managed to pose many, but related questions to group members in an interactive setting to ensure that ICT lecturers were free to give different insights to the study. As the interview processes continued, the authors used tape recorders to support and to clarify conversation by focus group members. There was also continuous jotting down the main points as given by the focus group members. Through the focus group interview process, the authors were able to study the members in their natural environments for person to person interview process. Other drawbacks as a result of the focus group interviews included validity of the study outcomes. This was overcome by the authors repeating some questions several times (Zikmund, Babin, Carr, \& Griffin, 2010).

\section{Procedure}

All protocol regarding the administration of the research questionnaires and interview schedules were followed. Different departments especially the ICT department assisted in distributing and collecting the completed questionnaires. As a requirement, the authors asked the ICT students and lecturers to sign consent forms in order to participate in the study. In addition, issues of voluntary participation were discussed. In total, 150 questionnaires were completed without errors and returned for analysis. Only 50 questionnaires were declared not authentic due to mistakes. The completed questionnaires were subjected to data analysis processes of collation, scoring and coding. Also, all the relevant information on interviews and focus group discussions were given priority.

\section{Data Analysis}

Inferential statistics of independent t-tests were applied to test the stated hypotheses. EL challenges were analysed using descriptive statistics. The authors employed statistical means in order to evaluate EL challenges to establish participants' responses (Welman, Kruger \& Mitchell, 2005). Besides the quantitative analysis, qualitative data was gathered through focus interviews. Qualitative data was analysed by organizing it into themes and different concepts. Thereafter, the authors described and discussed the findings. This was followed by descriptive narrations and comparisons of participants' responses to ascertain quality data set. Data analysis was divided in line with the stated hypotheses. An index was created for ELPCs; thus, a new variable was computed "extent of ELPCs using responses C15, C16, C17, C18, C19 and E32" through SPSS. The index "extent of personal challenges was constructed. Similar index for "technical support" was constructed from responses such as C13, C20 and D23. The three hypotheses as shown in figure 1 above were to test relationships between gender, background and broadband knowledge. Further consideration was given to generate descriptive data set such as the means and standard deviation to determine the degree of EL challenges. Furthermore, it is crucial to understand that in this study, a five-point Likert scale was employed. Thus, a mean below 3 (the median point) indicates "negative findings" whilst a mean score above 3 revealed "positive findings" 


\section{RESULTS AND INTERPRETATIONS}

Table 1 shows that $91(74.0 \%)$ of the females as compared to $32(26.0 \%)$ of the males are faced with challenges of e-learning than the males. The result implies that more females within institutions of higher learning experienced elearning challenges that the male counterparts. A number of contributing factors namely cultural, traditional and social in developing countries.

Table 1. Gender

\begin{tabular}{c|c|c}
\hline Gender & Frequency & $\%$ \\
\hline Male & 32.0 & $26.0 \%$ \\
\hline Female & 91.0 & $74.0 \%$ \\
\hline
\end{tabular}

From Table 2, ELPCs for males (mean=16.93) is higher that the mean ELPCs for females (mean=15.60). This means that the male participants have significantly higher ELPCs than the female counterparts. Several factors are contributors to these results.

Table 2. Group statistics of ELPCs by gender

\begin{tabular}{|c|c|c|c|c|c|}
\hline & Gender & $\mathbf{N}$ & Mean & $\begin{array}{c}\text { Std. } \\
\text { Deviation }\end{array}$ & $\begin{array}{l}\text { Latent Factor } \\
\text { coefficients }\end{array}$ \\
\hline \multirow{2}{*}{ Extend of ELPCs } & Male & 28 & 16.93 & 5.270 & .996 \\
\hline & Female & 75 & 15.60 & 7.765 & .550 \\
\hline
\end{tabular}

Table 3 depicts almost equal values of mean challenges though not significant. Generally, most personal challenges such as lack of connectivity (mean=3.678), costly ICT equipment (mean=3.365), lack of prior computer knowledge from high school (mean=3.348). In spite of these challenges, only the challenges of ICT and e-learning periods each time doing assignments was valued at $($ mean $=2.867)$ respectively.

Table 3. Summary of personal challenges

\begin{tabular}{|c|c|c|c|c|}
\hline Personal Challenges & $\mathbf{N}$ & Mean & Std. Deviation & $\begin{array}{l}\text { Latent Factor } \\
\text { coefficients }\end{array}$ \\
\hline $\begin{array}{l}\text { C15. To what extent have you encountered challenges during } \\
\text { e-learning due to lack of computers? }\end{array}$ & 118 & 3.331 & 1.384 & 0.676 \\
\hline $\begin{array}{l}\text { C16. To what extent have you encountered challenges during } \\
\text { e-learning due to lack internet connectivity? }\end{array}$ & 115 & 3.678 & 1.253 & 0.691 \\
\hline $\begin{array}{l}\text { C17. To what extent have you encountered challenges during } \\
\text { e-learning due to lack of student's readiness? }\end{array}$ & 116 & 3.310 & 1.153 & 0.446 \\
\hline $\begin{array}{l}\text { C18. To what extent have you encountered challenges during } \\
\text { e-learning due to costly equipment? }\end{array}$ & 115 & 3.365 & 1.441 & 0.705 \\
\hline $\begin{array}{l}\text { C19. To what extent have you encountered challenges during } \\
\text { e-learning due to lack of prior computer knowledge? }\end{array}$ & 115 & 3.348 & 1.364 & 0.709 \\
\hline $\begin{array}{l}\text { E32. Describe the challenges you face during ICT and e- } \\
\text { learning periods each time doing assignments. }\end{array}$ & 113 & 2.867 & 1.153 & 0.534 \\
\hline
\end{tabular}

Majority of institutional challenges were more than mean value of 3 . Table 4 revealed the challenges of e-learning due to lack of knowledgeable staff value with the mean value of 3.763. Next was e-learning challenges due to lack of infrastructure mean value of 3.410. This finding implies that students are faced with high proportion of institutional challenges regarding e-learning due to staff who lack the requisite knowledge. 
Table 4. Summary of e-learning Institutional challenges

\begin{tabular}{|c|c|c|c|c|}
\hline Institutional Challenges & $\mathbf{N}$ & Mean & Std. Deviation & $\begin{array}{c}\text { Latent Factor } \\
\text { coefficients }\end{array}$ \\
\hline $\begin{array}{l}\text { C14. To what extent have you encountered challenges during } \\
\text { e-learning due to lack of infrastructure? }\end{array}$ & 117 & 3.410 & 1.267 & 0.755 \\
\hline $\begin{array}{l}\text { C20. To what extent have you encountered challenges during } \\
\text { e-learning due to lack of knowledgeable staff? }\end{array}$ & 114 & 3.763 & 1.264 & 0.755 \\
\hline
\end{tabular}

Table 5 above shows high proportion of mean score of $93.8 \%$ pursued e-learning between the period of 3 and 5 years. This implies that the largest population of students were interested in ICT in spite of the challenges.

Table 5. Summary of e-learning background

\begin{tabular}{l|c|c|}
\hline $\begin{array}{c}\text { 7. For how long have you been engaging } \\
\text { in the e-learning at this campus? }\end{array}$ & Frequency & $\%$ \\
\hline Since I started at the institution & 117.0 & $98.3 \%$ \\
\hline Between 3 and 5 years & 2.0 & $1.7 \%$ \\
\hline
\end{tabular}

Based on table 6 above, 47 (39.2\%) of participants responded positively to the statement to have acquired computer training at high school. However, a high proportion of participants $73(60.8 \%)$ responded negatively to the same statement. This implies that during the period of high school, majority of participants were not trained on computer applications. It was therefore no wonder that most are faced with e-learning challenges.

Table 6. Personal challenges

\begin{tabular}{|l|c|c|}
\hline $\begin{array}{c}\text { 27. Did you have any training on } \\
\text { computer usage at high school? }\end{array}$ & Frequency & $\%$ \\
\hline Yes & 47.0 & $39.2 \%$ \\
\hline No & 73.0 & $60.8 \%$ \\
\hline $\begin{array}{c}\text { E28. Did you have any knowledge of } \\
\text { broadband internet access? }\end{array}$ & & $38.6 \%$ \\
\hline Yes & 44.0 & $61.4 \%$ \\
\hline No & 70.0 & $\%$ \\
\hline
\end{tabular}

Table 7 shows the majority $56(57.7 \%)$ of participants were well equipped with computers. However, 41 (42.3\%) were without adequate computers. This implies that there are other contributing personal challenges that impedes e-learning within the higher institutions of learning.

Table 7. Personal challenges

\begin{tabular}{|l|c|c|}
\hline $\begin{array}{c}\text { E29. Describe the computer lab } \\
\text { in your high school. }\end{array}$ & Frequency & $\%$ \\
\hline Well equipped with computers & 56.0 & $57.7 \%$ \\
\hline Lacked sufficient computers & 41.0 & $42.3 \%$ \\
\hline
\end{tabular}

From Table 8 majority ranked relatively low the ELPCs as indicated. The mean value of 2.548 was the response by participants who had efficient laboratories for receiving and sending information. On the other hand, the mean value of 2.473 was participants' responses to how good was the computer laboratories in high schools. This implies that these challenges contributed insignificantly to the challenges faced by participants. Thus, there are other contributors to e-learning in the learning environment. 
Table 8. Personal challenges

\begin{tabular}{|c|c|c|c|c|}
\hline & $\mathbf{N}$ & Mean & $\begin{array}{c}\text { Std. } \\
\text { Deviation }\end{array}$ & $\begin{array}{l}\text { Latent Factor } \\
\text { coefficients }\end{array}$ \\
\hline E30. How good was your computer lab in your high school? & 91 & 2.473 & 1.501 & 0.915 \\
\hline $\begin{array}{l}\text { E31. How efficient was your computer lab in your high } \\
\text { school in terms of receiving and sending information? }\end{array}$ & 104 & 2.548 & 1.343 & 0.915 \\
\hline
\end{tabular}

Table 9 depicts relatively low response to e-learning challenges. Responding to a statement on technical support, majority of participants have encountered low mean score (Mean=3.171) of lack of technical assistance. The implications could be that there are more underlining challenges given the fact that the mean score was not high.

Table 9. Technical Support

\begin{tabular}{|c|c|c|c|}
\hline & $\mathbf{N}$ & Mean & Std. Deviation \\
\hline $\begin{array}{l}\text { C13. To what extent have you encountered challenges } \\
\text { during e-learning due to lack of technical assistance? }\end{array}$ & 117 & 3.171 & 1.288 \\
\hline
\end{tabular}

Table 10 above depicts relatively high negative responses with mean score of 16.916 while others responded positively with a mean score of 14.359. This implies that the majority of the students did not agree that background knowledge in computers in high school impede on e-learning.

Table 10. Background in High School computers and ELPCs

\begin{tabular}{l|l|c|c|c|c|}
\hline & \multicolumn{2}{|c}{ Group Statistics } & \multicolumn{2}{c}{ Std. Error } \\
& $\begin{array}{c}\text { High school background } \\
\text { in computers }\end{array}$ & N & Mean & $\begin{array}{c}\text { Std. } \\
\text { Deviation }\end{array}$ & $\begin{array}{c}\text { Stoan } \\
\text { Mean }\end{array}$ \\
\hline \multirow{2}{*}{$\begin{array}{l}\text { Extend of e-learning personal } \\
\text { challenges }\end{array}$} & Yes & 39.000 & 14.359 & 4.343 & 0.695 \\
\cline { 2 - 7 } & $\mathrm{No}$ & 60.000 & 16.916 & 5.162 & 0.666 \\
\hline
\end{tabular}

Table 11 depicts relatively high negative responses with mean score of 16.58 while others responded positively with a mean score of 15.03. This implies that the majority of the students did not agree that broadband knowledge in computers in high school impede on e-learning.

Table 11. Knowledge of broadband and ELPCs

\begin{tabular}{|c|c|c|c|c|c|}
\hline \multicolumn{6}{|c|}{ Group Statistics } \\
\hline & $\begin{array}{l}\text { Knowledge of broadband } \\
\text { internet access }\end{array}$ & $\mathbf{N}$ & Mean & $\begin{array}{c}\text { Std. } \\
\text { Deviation }\end{array}$ & $\begin{array}{l}\text { Std. Error } \\
\text { Mean }\end{array}$ \\
\hline \multirow{2}{*}{$\begin{array}{l}\text { Extend of e-learning personal } \\
\text { challenges }\end{array}$} & Yes & 36.0000 & 15.0300 & 4.6260 & 0.7710 \\
\hline & No & 62.0000 & 16.5800 & 5.1330 & 0.6520 \\
\hline
\end{tabular}

\section{INFERENTIAL ANALYSIS}

\section{Testing Research Hypotheses}

Based on the conceptual framework (see figure 1), the authors performed t-tests to determine perceptions of gender, computer background knowledge and broadband knowledge with or without broadband of ICT students in terms of ELPCs. The three formulated hypotheses are stated throughout this section.

$\mathbf{H}_{1}$ : There is no significant differences between (gender) the male and female participants in terms of ELPCc. 
Table 12. Independent Samples Test: Gender and ELPCs

\begin{tabular}{|c|c|c|c|c|c|c|c|c|c|}
\hline \multirow[t]{2}{*}{$\begin{array}{c}\text { Extend of e-learning } \\
\text { personal challenges }\end{array}$} & \multicolumn{2}{|c|}{$\begin{array}{l}\text { Levene's Test for } \\
\text { Equality of Variances }\end{array}$} & \multicolumn{5}{|c|}{ t-test for Equality of Means } & \multicolumn{2}{|c|}{$\begin{array}{l}95 \% \text { Confidence } \\
\text { Interval of the } \\
\text { Difference }\end{array}$} \\
\hline & $\mathbf{F}$ & Sig. & $\mathbf{T}$ & Df & $\begin{array}{c}\text { Sig. } \\
\text { (2-tailed) }\end{array}$ & $\begin{array}{c}\text { Mean } \\
\text { Difference }\end{array}$ & $\begin{array}{l}\text { Std. Error } \\
\text { Difference }\end{array}$ & Lower & Upper \\
\hline $\begin{array}{l}\text { Equal variances } \\
\text { assumed }\end{array}$ & 0.0562 & 0.81 & 1.2231 & 101.00 & 0.2242 & 1.3286 & 1.086 & -0.82 & 3.4834 \\
\hline $\begin{array}{l}\text { Equal variances not } \\
\text { assumed }\end{array}$ & & & 1.1677 & 44.48 & 0.2492 & 1.3286 & 1.137 & -0.96 & 3.6209 \\
\hline
\end{tabular}

The findings regarding hypothesis 1 implies that both male and female ICT students suffer in terms of ELPCs as indicated by the $(\mathrm{P}$-value $=0.2242>0.05)$. However, stated in table 9 above, it became clear that male ICT students are found to experience (mean=16.93) more in terms of ELPCs that their female counterparts (mean=15.60). This could be due to the fact that more male ICT students came from high schools where there was a lack of ICT equipment such as computers and poorly designed computer laboratories. Also shown in Table 1 above fewer male students enrolled for e-learning programs in contrast to female enrollment. Furthermore, it can also be said that the male ICT students were under-qualified to be enrolled for e-learning. This deduction is supported by literature that few students lack enough basic computer skills prior to university studies (Nash, 2009). The findings from this study is inconsistent with similar study in Saudi Arabia Universities where the study revealed no differences between male and female ICT students (Hussein, 2011).

Table 13. Independent Samples Test: Background and ELPCs

\begin{tabular}{|c|c|c|c|c|c|c|c|c|c|}
\hline \multirow[t]{2}{*}{$\begin{array}{l}\text { Extend of e- } \\
\text { learning personal } \\
\text { challenges }\end{array}$} & \multicolumn{2}{|c|}{$\begin{array}{c}\text { Levene's Test for } \\
\text { Equality of Variances }\end{array}$} & \multicolumn{5}{|c|}{ t-test for Equality of Means } & \multicolumn{2}{|c|}{$\begin{array}{l}\text { 95\% Confidence } \\
\text { Interval of the } \\
\text { Difference }\end{array}$} \\
\hline & $\mathbf{F}$ & Sig. & $\mathbf{T}$ & Df & $\underset{\text { (2-tailed) }}{\text { Sig. }}$ & $\begin{array}{c}\text { Mean } \\
\text { Difference }\end{array}$ & $\begin{array}{l}\text { Std. Error } \\
\text { Difference }\end{array}$ & Lower & Upper \\
\hline $\begin{array}{l}\text { Equal variances } \\
\text { assumed }\end{array}$ & 1.304 & 0.256 & -2.559 & 97.000 & 0.012 & -2.557 & 0.999 & -4.541 & -0.574 \\
\hline $\begin{array}{l}\text { Equal variances } \\
\text { not assumed }\end{array}$ & & & -2.655 & 90.616 & 0.009 & -2.557 & 0.963 & -4.471 & -0.644 \\
\hline
\end{tabular}

$\mathbf{H}_{2}$ : There is no significant differences between participants with or without computer background in terms of ELPCs.

Hypothesis 2 stated that there were no significant differences between ICT students with background knowledge in computers as compared to ICT students without background knowledge in terms of ELPCs. Table 13 above indicates significant differences between ICT students with background knowledge in computer in terms of ELPCs ( $\mathrm{P}=$ value $0.0120<0.05$ ). ICT students with background knowledge in computer (mean $=4.3590$ ) appears to experience lesser ELPCs as compared to ICT students without background computer knowledge (mean=16.9167). This finding supports the general views that more successful students in e-learning are those who required prior knowledge in technological skills in particular to spur EL (Liaw \& Huang, 2011). Therefore, the current findings agree with a previous study that EL depends on infrastructure; as such institutions need total consistency and an organized network to assist EL programs (Khan, 2005).

H3: There is no significant differences between participants with or without broadband knowledge in terms of ELPCs. 
Table 14. Independent Samples Test; Knowledge of broadband and ELPCs

\begin{tabular}{|c|c|c|c|c|c|c|c|c|c|}
\hline \multirow[t]{2}{*}{$\begin{array}{l}\text { Extend of e- } \\
\text { learning personal } \\
\text { challenges }\end{array}$} & \multicolumn{2}{|c|}{$\begin{array}{c}\text { Levene's Test for } \\
\text { Equality of Variances }\end{array}$} & \multicolumn{5}{|c|}{ t-test for Equality of Means } & \multicolumn{2}{|c|}{$\begin{array}{l}\text { 95\% Confidence } \\
\text { Interval of the } \\
\text { Difference }\end{array}$} \\
\hline & $\mathbf{F}$ & Sig. & $\mathbf{t}$ & Df & $\begin{array}{c}\text { Sig. } \\
\text { (2-tailed) }\end{array}$ & $\begin{array}{c}\text { Mean } \\
\text { Difference }\end{array}$ & $\begin{array}{l}\text { Std. Error } \\
\text { Difference }\end{array}$ & Lower & Upper \\
\hline $\begin{array}{l}\text { Equal variances } \\
\text { assumed }\end{array}$ & 1.484 & 0.226 & -1.495 & 96.000 & 0.138 & -1.552 & 1.038 & -3.613 & 0.507 \\
\hline $\begin{array}{l}\text { Equal variances not } \\
\text { assumed }\end{array}$ & & & -1.538 & 79.589 & 0.128 & -1.552 & 1.009 & -3.562 & 0.456 \\
\hline
\end{tabular}

Hypothesis 3 as shown in Table 14 indicates that there are no significant differences between ICT students with broadband knowledge and ICT students without broadband knowledge in terms of ELPCs ( $p$ value $=0.13807>0.05$ ). According to the finding, ICT students with broadband knowledge (mean=15.03) experiences fewer ELPCs than ICT students without broadband knowledge (mean=16.58). This finding could be due to the fact that ICT students in both instances were not exposed to prior technological knowledge during their high school periods. In other words, ICT students with broadband knowledge and those without broadband knowledge experience almost similar difficulties. Given this finding, the hypothesis can therefore be accepted because there is no significant difference as stated. Based on the outcomes of this study, it can be confirmed that sentiments by academics and researchers bear similarities to this study. For instance, most academics argued that there are acute shortages of ICT equipment, lack of relevant skills and manpower and infrastructure shortages including inability to own computers and lack of connectivity (Asher, Duke \& Green, 2010). While e-learning is essential to enhance methods of teaching and learning across the higher education sectors, it is equally fair to state that ICT students in developing countries are constrained due to facilities such as lack of infrastructure, personal challenges including skills and funding (Wong, 2007; Mungania, 2003).

\section{DISCUSSION AND FINDINGS}

\section{Personal Challenges Experienced by ICT Students}

The personal challenges experienced by ICT students indicated that on average severe challenges are faced by the students. In other words, most personal challenges as shown in this study bear similarities to studies in developing countries (Rajesh, 2003; Heeks, 2002; Dhanarajan, 2001). Key among these challenges were lack of internet connectivity, costly ICT equipment, lack of prior computer knowledge from high school. These findings seem to suggest that even though over (60.8\%) ICT students registered to participate in the e-learning programs, only $39.2 \%$ were previously exposed to ICT equipment. It is therefore, not surprising that the majority of ICT students experienced a high level of challenges. A further indication of a high degree of non-participating in ICT programs as expected was because of the challenges. Most (61.4\%) of the students had no knowledge of broadband internet access. Other personal challenges as shown by a five-point Likert-scale summarises participants' responses by ICT students anchored as "strongly disagree" to "strongly agree". Comparing the challenges as shown in the table, the mean values are generally below 2.5 (standard deviation of 1.3) "a negative finding". A revelation that this outcome is not by any means surprising given the overall scientific views as expressed in literature.

Other personal challenges were highlighted in this study. For instance, more than half (57.7\%) ICT students indicated that their high schools' computer laboratories were well equipped. This revelation was in stark contrast to others (42.3\%) ICT students who stated that computer laboratories at high schools are poorly equipped. On the other hand, ICT students ranked two personal challenges "How good were your computer laboratories at high schools" and "how efficient were your computer laboratories in your high schools in receiving and sending information". These challenges were ranked through the mean scores of 2.473 and 2.548 respectively. Literature supports this claim that computer literacy still remains another cause for concern as most students and institutions of higher learning lack the required computer skills (Al-Fahad, 2010). 


\section{Institutional Challenges Experienced by ICT Students}

Through descriptive statistics of the mean, the findings by ICT students are shown above. Most institutional challenges were ranked with mean values of over 3. Among the challenges, ICT students obtained a mean score of 3.763 "the challenges due to lack of knowledgeable staff" as the most severe. This was trailed by another personal challenge; "due to lack of infrastructure" with the mean score of 3.410. These results displayed sentiments by academics and renowned authors the effect of institutional challenges on EL (Hewagamage, 2011). Whilst it may be true that institutions of higher learning in developing countries are faced with complex challenges, it is early to think that most institutional challenges can easily be solved. Providing enough e-learning to ICT students demand not only adequate infrastructure, but also skilled employees. The general challenges of infrastructure and other personal challenges including institutional problems impact significantly on e-learning as expected in developing countries including South Africa where in particular the higher education systems are in dire need of facilities (UNESCO, 2009).

\section{E-learning Challenges Experienced by ICT Students}

Table above summaries of e-learning background information. The majority (98.3\%) of ICT students were engaged in e-learning over the periods ranging between 3 and 5 years. This outcome implies the severity of challenges experienced over the study periods. These findings are in line with a recent study which revealed that most students were unable to successfully complete the programs. That being the situation, there seems to be a drastic shift within institutions of higher learning for ICT improvement as it is the sole responsibility of institutions to deliver excellent e-learning.

\section{Challenges of Technical Support Experienced by ICT Students}

ICT students were asked to rank using the mean score from the highest to the lowest "to what extent have you encountered challenges during e-learning due to lack of technical assistance". A mean score of 3.17 was finally reached on the above item by the ICT students. By indications, this finding means that the mean score of 3.17 represents "a positive outcome". Given this finding, it is fair to state that ICT students were unhappy with the technical assistance given at the institution. Simply put, the level of technical assistance provided lack the desired requirements.

\section{CONCLUSION AND RECOMMENDATIONS}

This study investigated the challenges of EL in a public institution of higher learning. The study revealed that EL challenges are constraints to students. These challenges include personal, institutional and technical among others. The study further tested three hypotheses based on gender, broadband knowledge and background knowledge. It came to light that in terms of gender, more male students faced challenges in contrast to the female students. Other hypotheses such as background knowledge have shown that students with computer knowledge experience minimal challenges during the EL programs. Drawing from these findings, recommendations were made to enable management to address these challenges that hinder EL in the institution. Besides these challenges, it became clear that EL is definitely beneficial to the students in accessing information and for workplace job opportunities. Similarly, the outcomes of this study provide an imminent pathway for management to help ICT students in order to derive future benefits not only in line with the educational requirements, but also for potential employment opportunities.

Institutions of higher learning need to increase investments not only in internet connectivity, but also in the relevant ICT infrastructure. By doing so, students would benefit from the growing degree of reliability and accessibility. Equally, it is up to management of higher institutions to provide prospective students with friendly ICT hardware and software that stimulates learning and encourages technical assistance. In designing learning programs, it is vital that cultural issues with specific references to students' background be considered. Given the fact that most students are from rural high schools where the bulk of ICT equipment is non-existent thus, these schools are ill-equipped. It is therefore critical that further cultural characteristics of students be examined, for instance, how individual students learn, interact and communicate constitutes a core e-learning foundation. Simply put, e-learning is an independent learning program; hence, the students are unlikely to understand the contents in complex languages. 


\section{AUTHOR BIOGRAPHIES}

Albert Tchey Agbenyegah obtained his MBA degree in 2003 had further education in UNISA where he graduated with honors in tax strategy. In 2013, he completed his PhD (Business Administration) at the North West University, Potchefstroom. As an emerging researcher, his research passion includes rural entrepreneurship and small businesses, technology education, business and strategic management. Email: alberta@dut.ac.za

Dr. Bongani Innocent Dlamini a PhD holder; a senior lecturer (HOD), Department of Applied Management Sciences, Durban University of Technology (DUT), Riverside Campus. Bongani's area of research, with specific focus in the business environment, human relations and entrepreneurship education. Email: dlaminibi@dut.ac.za

\section{REFERENCES}

Abdel-Wahab, A. (2008). Modeling students' intention to adopt e-learning a case from Egypt. Turkish Online Journal of Distance Education, 9(1), 157-168.

AL-Fahad, F. N. (2010). The learner's satisfaction toward online e-learning implemented in the college of Applied Studies and Community Services, King Saudi University, Saudi Arabia: Can e-learning replace the conventional system of education? Turkish Online Journal of Distance Education, 11(2), 61-72.

Andersson, A.S. \& Grönlund, Å. (2009). "A conceptual framework for e-learning in developing countries: A Critical review of research challenges", The Electronic Journal of Information Systems in Developing Countries, 38.

Asher A., Duke L. \& Green, D. (2010). The ERIAL project: ethnographic research in Illinois academic libraries. Academic Commons, 'Advancing towards liberal arts 3.0'. http://www.academiccommons.org/ commons/essay/erialproject cited in http://lisagoldresearch.wordpress.com/2011.

Bhalalusesa, R., Lukwaro, E. E. \& Clemence, M. (2013). Challenges of using e-learning management systems faced by the academic staff in distance-based institutions from developing countries: A case study of the Open University of Tanzania. Huia Journal of OUT, 14, 89-110.

Bryman, A. (2012). Social Research Methods. $4^{\text {th }}$ edition. Oxford University Press.

Cooper, D.R. \& Schindler, P.S. (2008). Marketing Research. New York, NY: McGraw-Hill.

Czernierwicz, L, Ravjee, N. \& Mlitwa, N. (2006). Higher Education Monitor Information and Communication Technologies (ICTs) and South African Higher Education: Mapping the Landscape. Council on Higher Education, 5, July. [Online] Available: http://www.che.ac.za. Accessed 10 December, 2017.

Dhanarajan, G. (2001). "Distance Education: promise, performance and potential," Open Learning (16:1), 61-68.

$\mathrm{Du}, \mathrm{Z}$., Fu, X., Zhao, C., Liu, Q. \& Liu, T. (2013). Interactive and collaborative e learning platform with integrated social software and learning management systems. Proceedings of the 2012 International Conference on Information Technology and software Engineering \& Digital Media Technology. Lecture notes in Electrical Engineering 212, Springer, 11-19.

Dumbrajs, S., Jagerb, T. De. \& Bergström-Nybergc, S. (2013). $9^{\text {th }}$ Grade students looking at their chemistry studies. Comparison between Finland and South Africa. 2nd Cyprus International Conference on Educational Research, (CY-ICER 2013) Science Direct. Social and Behavioral Sciences 89, $40-48$.

Flipsen, N.A. \& Van der Weide, T. (2009). 'Implementing gender issues in ICT', Africa Education Review 6(2), 308-323.

Hardgrave, B.C. \& Johnson, R.A. (2003). 'Toward an information systems development: The case of object-oriented', IEEE Transactions on Engineering Management 50(3), 322-336.

Heeks, R. (2002). "Information Systems and Developing Countries: Failure, Success, and Local Improvisations," The Information Society (18:2), 101-112.

Hewagamage, K.P. (2011). "M-Learning not an extension of e-Learning" based on a case study of Moodle VLE: M-Learn 2011, 10th world Conference on Mobile and Contextual Learning

Horn, N., Huygen, P., Woodward, S. \& Smith, K. (2009). Human and Social Development National Qualification Framework Level 3: Student's Book. Northlands: Macmillan.

Hsiao, C.H. \& Yang, C. (2011). 'The intellectual development of the technology acceptance model: A co-citation analysis', International Journal of Information Management 31(2), 128-136.

Hussein, H. B. (2011). Attitudes of Saudi universities faculty members toward using learning management system (JUSUR). Turkish Online Journal of Educational Technology, 10(2), 42-53.

Isabirye, A. K. and Dlodlo, N. (2014). Perceived Inhibitors of Innovative E-Learning Teaching Practice at a South African University of Technology, Mediterranean Journal of Social Sciences, 5, 390-398.

Jaffer, S., N'gambi, D. \& Czerniewicz, L. (2007). The role of ICTs in higher education in South Africa: One strategy for addressing teaching and learning challenges. International Journal of Education and ICT, 3, 131-142.

Jansen Van Vuuren, J.C. \& Coetzee, F.P. (2004). ICT Education and Training in Sub-Saharan Africa. Issues in Informing Science and Information Technology Education. Pretoria.

Kent, R. (2007). Marketing Research Approaches, Methods, and Applications in Europe. London: Thomson Learning.

Khan, B (2005), Managing E-learning Strategies: Design, Delivery, Implementation and Evolution, Information Science Publishing.

Kituyi, G. M., Moya, M. \& Kyeyune, R. (2012). A Framework for Implementing Sustainable e-learning Information Systems in Developing Countries. Journal of the Management University of Africa. VI (2074-4730):223-228. 
Kohn, T., Maier, R., Thalmann, s. (2008). Knowledge transfer with e-learning resources to developing countries - barriers and adaptive solutions. In: Breitner, M.H. et al, (eds): E-learning. Springer, Heidelberg.

Kombo, D.K. \& Tromp, D.L.A. (2006). Proposal and Thesis Writing. Nairobi, Kenya: Pauline's Publication Africa.

Leedy, P.D. \& Ormrod, J.E. (2005). Practical Research: Planning and Design. $8^{\text {th }}$ Ed. Upper Saddle River, NJ: Prentice Hall.

Lee, Y., Hsieh, Y. \& Hsu, C. (2011). Adding innovation diffusion theory to the technology acceptance model: Supporting employees' intensions to use e-learning systems. Journal of Educational Technology \& Society, 14(4), 124-137.

Levine, A. \& Sun, J. (2002). Barriers to Distance Education. [Online]. Available at http://www.acenet.edu/bookstore/pdf/distributedlearning/distributed-learning-06.pdf. (Accessed 23rd January 2017).

Leontitsis, A. \& Pagge, J. (2007). 'A simulation approach on Cronbach's alpha statistical significance', Mathematics and Computers in Simulation 73(5), 336-340.

Liaw, S. S., \& Huang, H. M. (2011). A Study of Investigating Learners Attitudes toward E-Learning. In 2011 5th International Conference on Distance Learning and Education, 12: 28-32).

Merriam, S.B. (2009). 'Dealing with validity, reliability, and ethics', in S.B. Merriam (ed.), Qualitative research: A guide to design and implementation, 209-235, Jossey-Bass, San Francisco.

Moll, I., Adam, F., Backhouse, J. \& Mhlang, E. (2007). Status Report on ICTs and Higher Education in South Africa. http://www.judybackhouse.com/pdfs/saide_status_of_elearning_in_sa.pdf.

Mungania, P. (2003), “The Seven E-learning Barriers Facing Employees.” Report University of Louisville.

Nani, G.V. (2011). Challenges faced by Zimbabwean urban women entrepreneurs. PhD Thesis. Bloemfontein: University of Free State.

Nash, J. (2009). Computer skills of first-year students at a South African university. Proceedings of the 2009 Annual Conference of the Southern African Computer Lecturers Association.

OECD (2005) E-learning in tertiary education: where do we stand? Paris: OECD/CERI Schiffman, Stephen, Vignare, Karen \& Geith, Christine (2007) Why do higher education institutions pursue online education? Journal of Asynchronous Learning Networks, 11(2): 61-71.

OERAfrica, (2014). Case studies: delivering eLearning in South Africa. http://www.oerafrica.org/supporting-distance-learners/casestudies-delivering-elearningsouth-africa. Accessed on 7th November 2017.

Omidinia, S., Masrom, M. \& Selamat, H. (2011). "Review of E-Learning and ICT Infrastructure in Developing Countries (Case Study of Iran)", American Journal of Economics and Business Administration. 3(1), 120-125.

Oye, N. D., Salleh, M. \& Iahad, N. A. (2010). Holistic E-learning in Nigerian Higher Education Institutions. Journal of Computing, 2(11), 20-26.

Rajesh, M. (2003). "A Study of the problems associated with ICT adaptability in Developing Countries in the context of Distance Education," The Turkish Online Journal of Distance Education (4:2) http://tojde.anadolu.edu.tr/tojde10/articles/Rajesh.htm.

Reddy, V., Gastrow, M., Juan A. \& Roberts, B. (2013). 'Public attitudes to science in South Africa', South African Journal of Science 109, 1-8. http://dx.doi.org/10.1590/ sajs.2013/1200

Rubens, N., Kaplan, D., \& Okamoto, T. (2011). “E-learning 3.0: Anyone, Anywhere, Anytime and Al”. Available: http://activeintelligence.org/wp-content/papercite-data/pdf/elearning-30-rubens-spel-2011-preprint.pdf (Accessed: 19 Oct 2019.

Rienties, B., Brouwer, N. \& Lygo-Barker, S. (2013). 'The effects of online professional development on higher education teachers' beliefs and intentions towards learning facilitation and technology', Teaching and Teacher Education 29, 122-131.

Roffe, Ian. (2004). Innovation and E-Learning. Cardiff: University of Wales Press.

Royse, D. (2008). Research Methods in Social Work. 5th Ed. Belmont: Thomson Brooks.

Sambrook, S. (2003). “E-learning in Small Organizations.” Education + Training, 45, (8/9), 506-516.

Sangra, A., Vlachopoulos, D. \& Cabrera, N. (2012). "Building an Inclusive Definition of E-Learning: An Approach to the Conceptual Framework", International Review of Research in Open and Distance Learning, 13 (2), 145-159.

Sanyal, B. C. (2001). New functions of higher education and ICT to achieve education for all, Paper prepared for the Expert Roundtable on University and Technology-for- Literacy and Education Partnership in Developing Countries, International Institute for Educational Planning, UNESCO, September 10 to 12, Paris.

Sife, A., Lwoga, E. \& Sanga, C. (2007). "New technologies for teaching and learning: Challenges for higher learning institutions in developing countries", International Journal of Education and Development using ICT, 3(2), 57-67.

Stevenson, A. (2010). Oxford Dictionary of English. 3rd ed. Oxford University Press. New York

UNESCO (2009). UNESCO portal on Higher Education Institutions: from http://portal.unesco.org/education/en/ev.php

Wong, D. (2007). "A critical literature review on e-learning limitations”, School of Management \& Information Technology, UCSI.

Welman, J.D., Kruger, S.J. \& Mitchell. B. (2005). Research Methodology. $3^{\text {rd }}$ Ed. Cape Town: Oxford University Press.

Wilson, J. (2010). Essentials of business research. A guide to doing your research project. Great Britain: Sage Publications

Zikmund, W., Babin, B. J., Carr, J. C. \& Griffin, M. (2010). Business Research Methods (8 ${ }^{\text {th }}$ Ed.). Victoria, Australia: South-Western, Cengage Learning. 